\title{
Fundamental Parameters for the Stiffness and Strength Control of Artificially Cemented Sand
}

\author{
Nilo Cesar Consoli, Ph.D. ${ }^{1}$; António Viana da Fonseca, D.Sc. ${ }^{2}$; Rodrigo Caberlon Cruz, D.Sc. ${ }^{3}$; and \\ Karla Salvagni Heineck, D.Sc. ${ }^{4}$
}

\begin{abstract}
The treatment of soils with cement is an attractive technique when the project requires improvement of the local soil for the construction of subgrades for rail tracks, as a support layer for shallow foundations and to prevent sand liquefaction. As reported by Consoli et al. in 2007, a unique dosage methodology has been established based on rational criteria where the voids/cement ratio plays a fundamental role in the assessment of the target unconfined compressive strength. The present study broadened the research carried out by Consoli et al. in 2007 through quantifying quantifies the influence of voids/cement ratio on the initial shear modulus $\left(G_{0}\right)$ and MohrCoulomb effective strength parameters $\left(c^{\prime}, \phi^{\prime}\right)$ of an artificially cemented sand. A number of unconfined compression and triaxial compression tests with bender elements measurements were carried out. It was shown that the void/cement ratio defined as the ratio between the volume of voids of the compacted mixture and the volume of cement is an appropriate parameter to assess both initial stiffness and effective strength of the sand-cement mixture studied.
\end{abstract}

DOI: $10.1061 /($ ASCE)GT.1943-5606.0000008

CE Database subject headings: Cements; Compression tests; Triaxial tests; Soil compaction; Subgrades; Railroad tracks.

\section{Introduction}

In spite of the common use of Portland cement in the improvement of local soils, there are no dosage methodologies based on rational criteria as in the case of the concrete technology, where the water/cement ratio plays a fundamental role in the assessment of the target strength or stiffness. In recent work the soil-cement ratio has been assessed by numerous laboratory tests that aim to find the minimum amount of cement that meets the target properties in terms of strength and durability. This approach probably results from the fact that soil-cement shows a complex behavior that is affected by many factors, for example the amount of cement, and the porosity and moisture content at the time of compaction (Clough et al. 1981; Tatsuoka and Shibuya 1992; Huang and Airey 1998; Porbaha et al. 2000; Horpibulsuk et al. 2003; Consoli et al. 2003,2006,2009; Thomé et al. 2005; Dalla Rosa et al. 2008).

\footnotetext{
${ }^{1}$ Associate Professor, Dept. of Civil Engineering, Federal Univ. of Rio Grande do Sul, Av. Osvaldo Aranha, 99, 3 Andar, CEP 90035-190 Porto Alegre, Rio Grande do Sul, Brazil (corresponding author). E-mail: consoli@ufrgs.br

${ }^{2}$ Associate Professor, Faculty of Engineering, Univ. of Porto, Rua Dr. Roberto Frias, s/n, 4200-465 Porto, Portugal. E-mail: viana@ fe.up.pt

${ }^{3}$ Research Fellow, Dept. of Civil Engineering, Federal Univ. of Rio Grande do Sul, Av. Osvaldo Aranha, 99, 3 Andar, CEP 90035-190 Porto Alegre, Rio Grande do Sul, Brazil. E-mail: rccaberlon@hotmail.com

${ }^{4}$ Adjunct Professor, Dept. of Civil Engineering, Federal Univ. of Rio Grande do Sul, Av. Osvaldo Aranha, 99, 3 Andar, CEP 90035-190 Porto Alegre, Rio Grande do Sul, Brazil. E-mail: karla@ppgec.ufrgs.br

Note. This manuscript was submitted on January 12, 2008; approved on January 30, 2009; published online on February 13, 2009. Discussion period open until February 1, 2010; separate discussions must be submitted for individual papers. This technical note is part of the Journal of Geotechnical and Geoenvironmental Engineering, Vol. 135, No. 9, September 1, 2009. CASCE, ISSN 1090-0241/2009/9-1347-1353/ $\$ 25.00$.
}

This study therefore aims to quantify the influence of the amount of cement and porosity (here associated to voids/cement ratio) on the initial shear modulus $\left(G_{0}\right)$ and effective strength parameters $\left(c^{\prime}, \phi^{\prime}\right)$ of an artificially cemented sand.

\section{Experimental Program}

The experimental program was carried out in two parts. First, the geotechnical properties of the soil and cement were characterized. Then, a number of unconfined compression tests were carried out, as discussed below. Triaxial compression tests with measurements of initial stiffness were also executed in specimens under distinct effective confining pressures and voids/cement ratio.

\section{Materials}

The sand used in the testing was obtained from the region of Osorio near Porto Alegre in southern Brazil, being classified (ASTM 1993) as nonplastic uniform fine sand (SP) with rounded particle shape and specific gravity of the solids 2.63. Mineralogical analysis showed that sand particles are predominantly quartz. The grain size is purely fine sand with a mean effective diameter $\left(D_{50}\right)$ of $0.16 \mathrm{~mm}$, being the uniformity and curvature coefficients of 1.9 and 1.2, respectively. The minimum and maximum void ratios are 0.6 and 0.9 , respectively. The angle of shearing resistance at constant volume is about $30^{\circ}$.

Portland cement of high initial strength (Type III) was used as the cementing agent. Its fast gain of strength allowed the adoption of 7 days as the curing time. The unconfined compressive strength of 7 days of curing using such cement is equivalent the unconfined compressive strength of 28 days of curing using ordinary Portland cement (Type I) (Brazilian Standard Association 1991). The specific gravity of the cement grains is 3.15 . Distilled water 
was used for the characterization tests, but for molding specimens for the compression tests tap water was used.

\section{Methods}

\section{Molding and Curing of Specimens}

For all testing, cylindrical specimens, $50 \mathrm{~mm}$ in diameter and 100 $\mathrm{mm}$ high, were used (height to diameter ratio=2). After the sand, cement and water were weighed, the sand and cement were mixed until the mixture acquired a uniform consistency. The water was then added continuing the mixture process until a homogeneous paste was created. The amount of cement for each mixture was calculated based on the mass of dry soil and the target moisture content.

After mixing sufficient material for one specimen, the mixture was stored in a covered container to avoid moisture losses before subsequent compaction. The time it took to prepare (mix and compact) was always less than $1 \mathrm{~h}$, which is much shorter than the initial setting time of $3.25 \mathrm{~h}$ of the Portland cement used. The specimen was then statically compacted in three layers inside a cylindrical split mold, which was lubricated, so that each layer reached the specified dry density. The top of each layer was slightly scarified. After the molding process, the specimen was immediately extracted from the split mold, and its weight, diameter and height measured with accuracies of about $0.01 \mathrm{~g}$ and 0.1 $\mathrm{mm}$. The samples were then placed within plastic bags to avoid significant variations of moisture content. They were cured in a humid room at $23 \pm 2{ }^{\circ} \mathrm{C}$ and relative humidity above $95 \%$ for 6 days.

The samples were considered suitable for testing if they met the following tolerances:

- Dry density $\left(\gamma_{d}\right)$ within $\pm 1 \%$ of target value.

- Moisture content $(\omega)$ within $\pm 0.5 \%$ of the target value.

- Diameter within $\pm 0.5 \mathrm{~mm}$.

- Height within $\pm 1 \mathrm{~mm}$.

It is important to point out that the dry density $\left(\gamma_{d}\right)$ of the specimens was calculated as the dry mass of the soil and cement divided by the total volume of the sample. To keep the dry density $\left(\gamma_{d}\right)$ of the specimen constant with increasing cement content, a small portion of the soil was replaced by cement. As the specific gravity of the cement grains (3.15) is greater than the specific gravity of the soil grains (2.63), for the calculation of void ratio and porosity, a composite specific gravity based on the soil and cement percentages in the specimen was used.

\section{Unconfined Compression Tests}

Unconfined compression tests have been used in most of the experimental programs reported in the literature to verify the effectiveness of the stabilization with cement or to access the importance of influencing factors on the strength of cemented soils. One of the reasons for this is the accumulated experience with this kind of test for concrete. The test is also simple and fast while being reliable and cheap. An automatic loading machine, with maximum capacity of $50 \mathrm{kN}$ and load cells with capacities of 10 and $50 \mathrm{kN}$ and resolutions of 0.005 and $0.023 \mathrm{kN}$, respectively, were used for the unconfined compression tests.

After curing in a humid room for 6 days, the specimens were submerged in a water tank for $24 \mathrm{~h}$ for saturation and to minimize suction, totalizing 7 days as the curing time period. The water temperature was controlled and maintained at $23 \pm 3{ }^{\circ} \mathrm{C}$. Immedi- ately before the test, the specimens were taken out the tank and dried superficially with an absorbent cloth. Then, the unconfined compression test was carried out and the maximum load reached by the specimen recorded. As acceptance criteria, it was stipulated that the individual strengths of three specimens, molded with the same characteristics, should not deviate by more than $10 \%$ from the mean strength.

\section{Triaxial Compression Tests}

Drained triaxial compression tests were carried out under controlled deformation at a displacement rate of $0.0173 \mathrm{~mm} / \mathrm{min}$. Pressure transducers monitored the confining stress, while the deviatoric load was measured with a load cell with a capacity of $10 \mathrm{kN}$ and a resolution of $0.005 \mathrm{kN}$, positioned internally to the chamber. The axial strains were measured through two independent systems. An internal system, using two load deformation transducer (LDT) sensors (Goto et al. 1991), allowed the measurement of the initial strains with resolution smaller than $1 \mu \mathrm{m}$. There was also a LVDT with a resolution smaller than $10 \mu \mathrm{m}$, measuring the relative displacement between the triaxial chamber and the loading piston. The volumetric strain was measured by an Imperial College volume gauge (Maswoswe 1985) connected to the drainage outlet. Full drainage during shearing was verified by measuring the excess pore pressure at the opposite end of the specimen to the drainage.

The execution of the triaxial tests followed the general procedures described by British Standard Methods of Test (1990). The specimens were saturated under back pressures up to $400 \mathrm{kPa}$ (saturation was monitored in each test-ensuring $B$ values of about 1.0 for all specimens) and the effective confining pressure was 20,200 , or $400 \mathrm{kPa}$, after that, the axial load was applied drained until failure. For the calculation of the applied stresses, the area corrections proposed by La Rochelle et al. (1988) were adopted. From the observations of the rupture shapes of the specimens, it was considered that the samples suffered deformation as a cylinder until reaching the peak stress. After the peak it was considered that the deformations were a combination of bulging and sliding on a shear plane. Nonlubricated ends were used in triaxial testing carried out in present research.

\section{Bender Element Tests}

Bender elements are currently a standard technique for deriving the elastic shear modulus of a soil at very small strains. In bender element tests (BETs), the maximum shear strain was estimated by Dyvik and Madshus (1985) to be less than $10^{-5}$, so that the shear modulus determined is $G_{0}$, relevant to very small strains (Viggiani and Atkinson 1995). Bender element systems can be set up in most laboratory apparatus, but are particularly versatile when used in the triaxial test. The time difference between the transmission and reception represents the travel time through the sample from which the velocity of the shear wave $V_{s}$ may be calculated and hence the elastic shear modulus of the soil is given by Eq. (1)

$$
G_{0}=\rho V_{s}^{2}=\rho\left(\frac{L^{2}}{t^{2}}\right)
$$

where $\rho=$ total mass density of the soil; $L=$ tip to tip length between the elements; and $t=$ travel time of the shear wave through the sample. Shear waves were vertically propagated and horizontally polarized since the piezotransducers were vertically encastrated in base and top caps of triaxial specimens. 


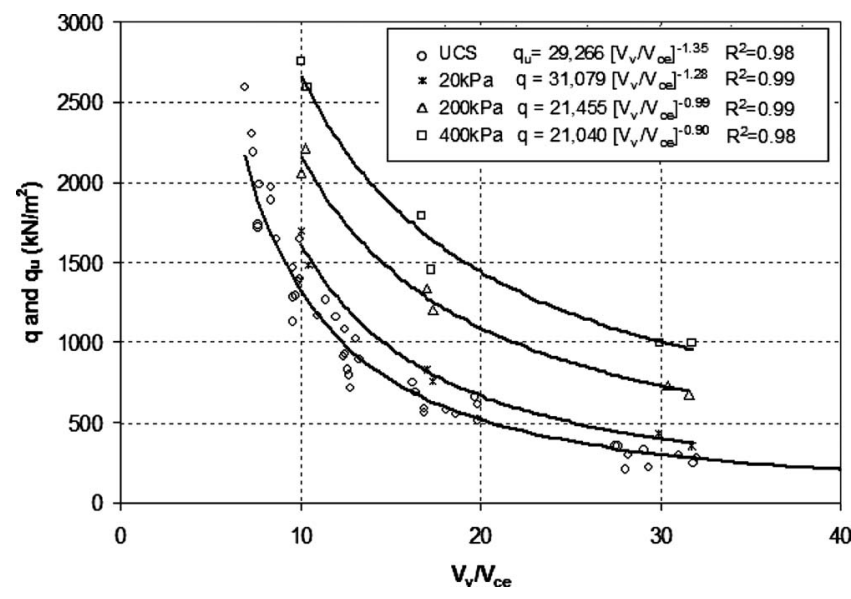

Fig. 1. Variation of unconfined compression strength $\left(q_{u}\right)$ and peak deviator stress ( $q$-for effective confining pressures of 20, 200, and $400 \mathrm{kPa})$ with void/cement ratio $\left(V_{v} / V_{\mathrm{ce}}\right)$

For the cemented samples studied in the present work, a slot was precut in the specimen to avoid damaging the element or sample. The test procedures and methods of interpretation followed Jovicic et al. (1996) and Viana da Fonseca et al. (2009).

\section{Program of Unconfined Compression Tests}

The unconfined compression tests (together with sand characterization) constituted the first part of this research. The program was chosen in such a way as to evaluate the voids/cement ratio.

The molding points were chosen considering void ratios of $0.68,0.73$, and 0.80 , with the same moisture content (about $10 \%)$. Each point was molded with six different cement percentages: $1,3,5,7,9$, and $12 \%$. These percentages were chosen considering the Brazilian and international experience with soil cement (e.g., Mitchell 1981; Consoli et al. 2003, 2006, 2007), both in experimental and practical work. Because of the typical scattering of data for unconfined compression tests, for each point three specimens were tested.

\section{Results}

\section{Effect of Voids/Cement Ratio}

Fig. 1 presents the unconfined compression strength as a function of the voids/cement ratio $\left(V_{v} / V_{\text {ce }}\right)$. Consoli et al. (2007) defined $V_{v} / V_{\text {ce }}$ as the absolute volume of voids (water+air) divided by the absolute volume of cement. A relation between $q_{u}$ and $V_{v} / V_{\text {ce }}$ [see Eq. (2)]

$$
q_{u}(\mathrm{kPa})=29,266\left[\frac{V_{v}}{V_{\mathrm{ce}}}\right]^{-1.35}
$$

presents a high coefficient of determination $\left(R^{2}=0.98\right)$ for the sand cement studied (see Fig. 1).

Eighteen consolidated isotropically drained triaxial compression tests were also carried out with the aim of examining the stress-strain behavior of specimens with the same voids/cement ratio (according to the $q_{u}-V_{v} / V_{\text {ce }}$ curve), but different absolute values of porosity and cement content. After saturation and application of the effective confining stresses $(20,200$, and $400 \mathrm{kPa})$, bender elements inserted on the top and bottom caps of the triaxial equipment were used to measure initial stiffness $\left(G_{0}\right)$. Three values for the ratio $V_{v} / V_{\text {ce }}(10,17$, and 30) were chosen representing the $q_{u}-V_{v} / V_{\text {ce }}$ curve obtained in Fig. 1. Table 1 presents the results of the triaxial tests.

Fig. 2 presents the deviator stress-axial strain-volumetric strain behavior for specimens with $V_{v} / V_{\text {ce }}=10$ under effective confining pressures of 20,200 , and $400 \mathrm{kPa}$. Results show that specimens with the same voids/cement ratio, but different absolute values of porosity and cement content, at any specific effective confining pressure [Figs. $2(\mathrm{a}-\mathrm{c})$, respectively, for confining pressures of 20,200 , and $400 \mathrm{kPa}$ ] have about the same peak

Table 1. Summary of the Triaxial Compression Tests

\begin{tabular}{|c|c|c|c|c|c|c|c|c|}
\hline Specimen & $\begin{array}{c}\text { Effective } \\
\mathrm{CP} \\
(\mathrm{kPa})\end{array}$ & $\begin{array}{c}\text { Cement } \\
\text { content } \\
(\%)\end{array}$ & $e$ & $\begin{array}{c}V_{v} \\
\left(\mathrm{~cm}^{3}\right)\end{array}$ & $\begin{array}{c}V_{\mathrm{ce}} \\
\left(\mathrm{cm}^{3}\right)\end{array}$ & $V_{v} / V_{\mathrm{ce}}$ & $\begin{array}{r}q_{\text {máx }} \\
(\mathrm{kPa}) \\
\end{array}$ & $\begin{array}{c}G_{0} \\
(\mathrm{MPa}) \\
\end{array}$ \\
\hline TRI-01 & 20 & 3.0 & 0.78 & 248.7 & 7.8 & 31.8 & 350.2 & 432.9 \\
\hline TRI-02 & 200 & 3.0 & 0.78 & 246.8 & 7.8 & 31.6 & 677.8 & 795.4 \\
\hline TRI-03 & 400 & 3.0 & 0.78 & 249.0 & 7.9 & 31.7 & 995.2 & 790.6 \\
\hline TRI-04 & 20 & 3.3 & 0.81 & 251.9 & 8.4 & 29.8 & 429.7 & 736.2 \\
\hline TRI-05 & 200 & 3.3 & 0.82 & 254.8 & 8.4 & 30.4 & 735.1 & 740.9 \\
\hline TRI-06 & 400 & 3.3 & 0.81 & 252.6 & 8.4 & 29.9 & 995.5 & 745.6 \\
\hline TRI-07 & 20 & 5.0 & 0.71 & 236.4 & 13.6 & 17.3 & 828.1 & 924.2 \\
\hline TRI-08 & 200 & 5.0 & 0.71 & 236.3 & 13.6 & 17.3 & $1,340.8$ & $1,088.2$ \\
\hline TRI-09 & 400 & 5.0 & 0.70 & 235.2 & 13.6 & 17.2 & $1,788.9$ & $1,295.8$ \\
\hline TRI-10 & 20 & 6.0 & 0.82 & 254.3 & 14.9 & 17.1 & 759.5 & 764.9 \\
\hline TRI-11 & 200 & 6.0 & 0.82 & 253.3 & 14.9 & 17.0 & $1,198.1$ & 863.4 \\
\hline TRI-12 & 400 & 6.0 & 0.80 & 251.5 & 15.1 & 16.7 & $1,450.6$ & $1,091.5$ \\
\hline TRI-13 & 20 & 8.6 & 0.71 & 235.0 & 22.5 & 10.4 & $1,479.7$ & $1,613.7$ \\
\hline TRI-14 & 200 & 8.6 & 0.69 & 231.0 & 22.5 & 10.3 & $2,215.1$ & $1,681.6$ \\
\hline TRI-15 & 400 & 8.6 & 0.70 & 234.2 & 22.5 & 10.4 & $2,594.4$ & $1,775.0$ \\
\hline TRI-16 & 20 & 10.3 & 0.80 & 249.4 & 24.8 & 10.0 & $1,697.4$ & $1,301.8$ \\
\hline TRI-17 & 200 & 10.3 & 0.80 & 250.1 & 24.8 & 10.1 & $2,061.9$ & $1,762.5$ \\
\hline TRI-18 & 400 & 10.3 & 0.80 & 249.9 & 24.8 & 10.1 & $2,753.4$ & $1,951.3$ \\
\hline
\end{tabular}



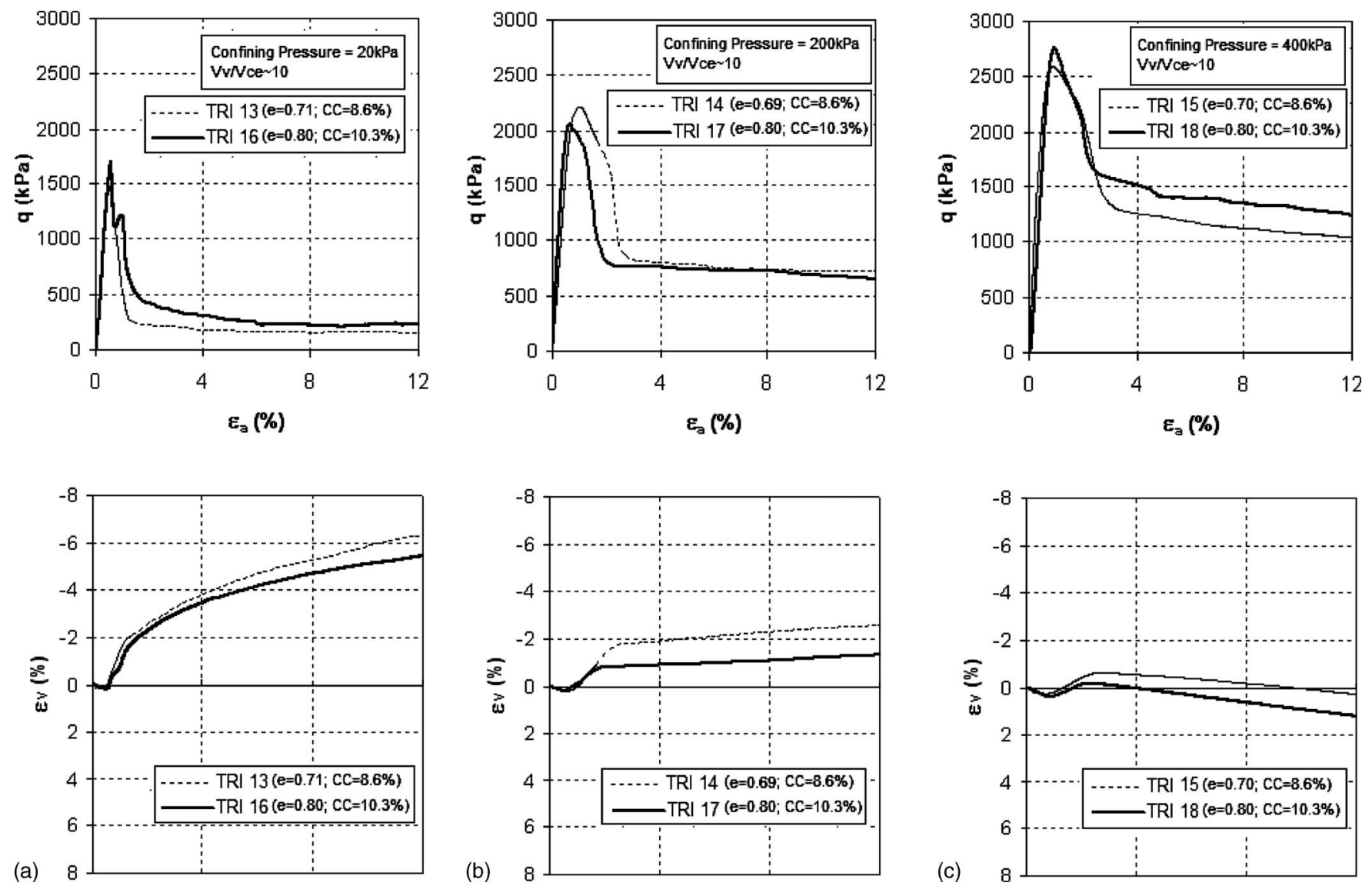

Fig. 2. Stress-axial strain-volumetric strain curves for the drained triaxial tests (TRI-13 to TRI-18) for $V_{v} / V_{\text {ce }}=10$ and effective confining pressures of (a) $20 \mathrm{kPa}$; (b) $200 \mathrm{kPa}$; and (c) $400 \mathrm{kPa}$

strengths, as well as the whole deviator stress-axial strainvolumetric strain curve up to peak, confirming that the voids/ cement ratio- $q_{u}$ strength normalization holds for specimens under effective confining pressures, and normalization can be extended to the whole deviator stress-axial strain-volumetric strain curve (at least up to peak and consequent opening of a shear band in the specimens).

Fig. 3 presents the deviator stress-axial strain-volumetric strain behavior of specimens with a unique effective confining pressure $(200 \mathrm{kPa})$ and the three studied voids/cement ratios, 10, 17, and 30 . It can be seen that the conclusions obtained for $V_{v} / V_{\mathrm{ce}}=10$ can be extended to $V_{v} / V_{\mathrm{ce}}=17$ and $V_{v} / V_{\mathrm{ce}}=30$ (and so for any value of $\left.V_{v} / V_{\text {ce }}\right)$. It can be clearly observed in Fig. 3 that the increase of the voids/cement ratio $\left(V_{v} / V_{\text {ce }}\right)$ from 10 to 30 comes together with a reduction in the brittleness of the cemented soil, changing from dramatically brittle $\left(V_{v} / V_{\text {ce }}=10\right)$ to nearly ductile $\left(V_{v} / V_{\mathrm{ce}}=30\right)$ behavior.

Fig. 1 also presents the peak compression strength ( $q$ for the three effective confining pressures used in the research) as a function of the voids/cement ratio. Good correlations (coefficient of determination ranging from $R^{2}=0.98-0.99$ ), valid for the studied range, can be observed between this ratio and the peak compression strength $(q)$ of the sand cement studied [see Eq. (3) for $\mathrm{CP}=20 \mathrm{kPa}$, Eq. (4) for $\mathrm{CP}=200 \mathrm{kPa}$ and Eq. (5) for $\mathrm{CP}=400 \mathrm{kPa}$ ]

$$
\begin{aligned}
& q(\mathrm{kPa})=31,079\left[\frac{V v}{V c e}\right]^{-1.28} \\
& q(\mathrm{kPa})=21,455\left[\frac{V v}{V c e}\right]^{-0.99} \\
& q(\mathrm{kPa})=21,040\left[\frac{V v}{V c e}\right]^{-0.90}
\end{aligned}
$$

All optimum fitting curves present similar format, with higher triaxial effective confining pressures positioning above each other and above the unconfined compression curve, due to the effect of the effective confining pressure on the strength.

Fig. 4 presents the peak strength envelopes for $V_{v} / V_{\mathrm{ce}}=10,17$, and 30 considering all triaxial data for each voids/cement ratio, as well as the UCS results. The cohesion intercept $\left(c^{\prime}\right)$ and angle of shearing resistance $\left(\phi^{\prime}\right)$ for each voids/cement ratio are also presented in Fig. 4. Values of $c^{\prime}$ and $\phi^{\prime}$ reduce with increasing $V_{v} / V_{\text {ce }}$ values. Fig. 5 presents the correlations of the voids/cement ratio with peak strength parameters cohesion intercept [see Eq. (6)] and angle of shearing resistance [see Eq. (7)]

$$
c^{\prime}(\mathrm{kPa})=4,430.4\left[\frac{V v}{V c e}\right]^{-1.1}
$$



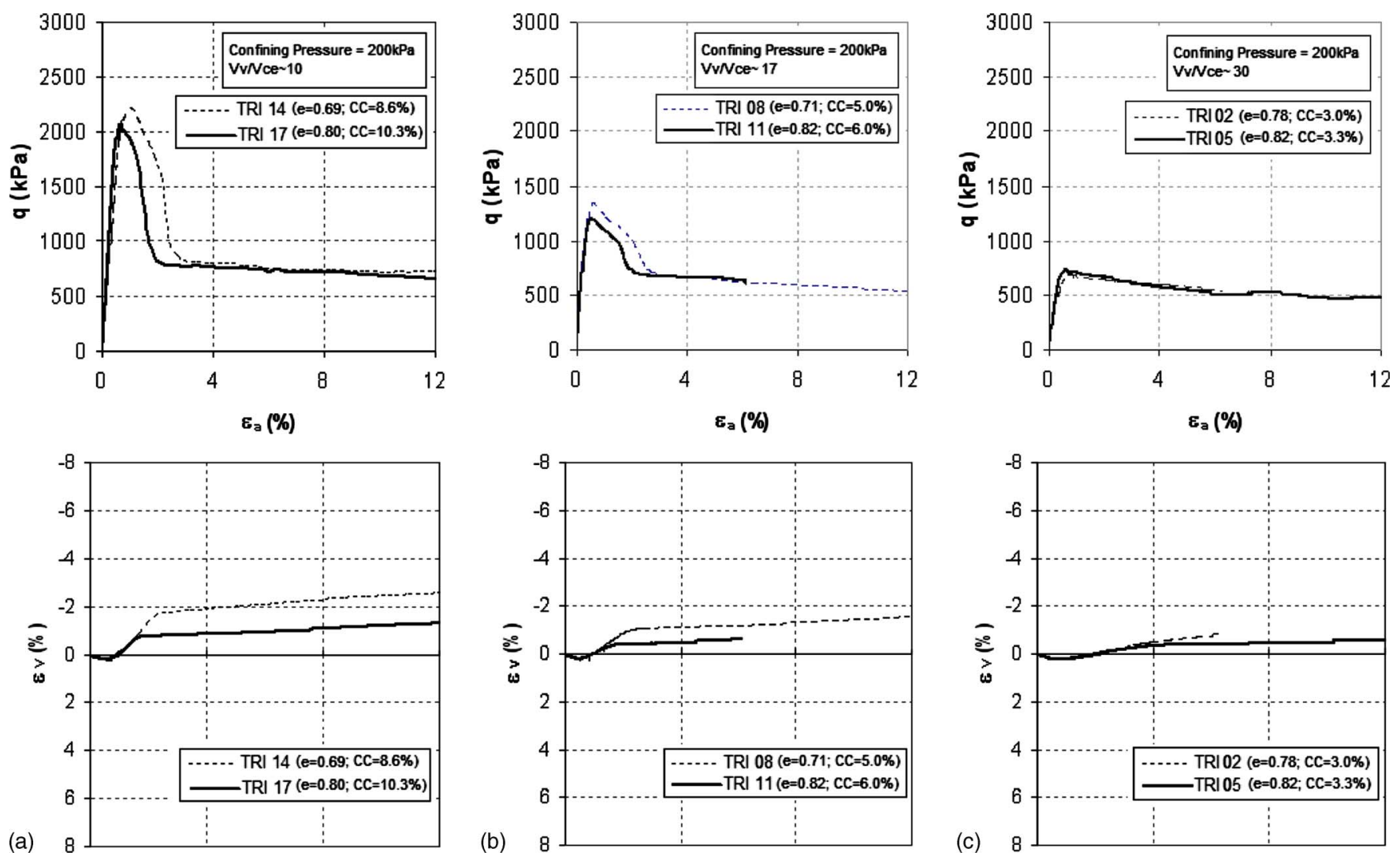

Fig. 3. Stress-axial strain-volumetric strain curves for the drained triaxial tests (TRI-2, TRI-5, TRI-8, TRI-11, TRI-14, and TRI-17) for effective confining stresses of $200 \mathrm{kPa}$ and (a) $V_{v} / V_{\mathrm{ce}}=10$; (b) $V_{v} / V_{\mathrm{ce}}=17$; and (c) $V_{v} / V_{\mathrm{ce}}=30$

$$
\phi^{\prime}(\operatorname{deg})=79\left[\frac{V v}{V c e}\right]^{-0.31}
$$

The relation [see Eq. (8)] between the estimated initial shear modulus $\left(G_{0}\right)$ and $V_{v} / V_{\text {ce }}$ (considering all effective confining pressures) is shown in Fig. 6

$$
G_{0}(\mathrm{MPa})=10,086\left[\frac{V_{v}}{V_{\text {ce }}}\right]^{-0.79}
$$

The optimum fitting curves of the unconfined compression strength $\left(q_{u}\right)$ of the sand cement studied and initial shear modulus

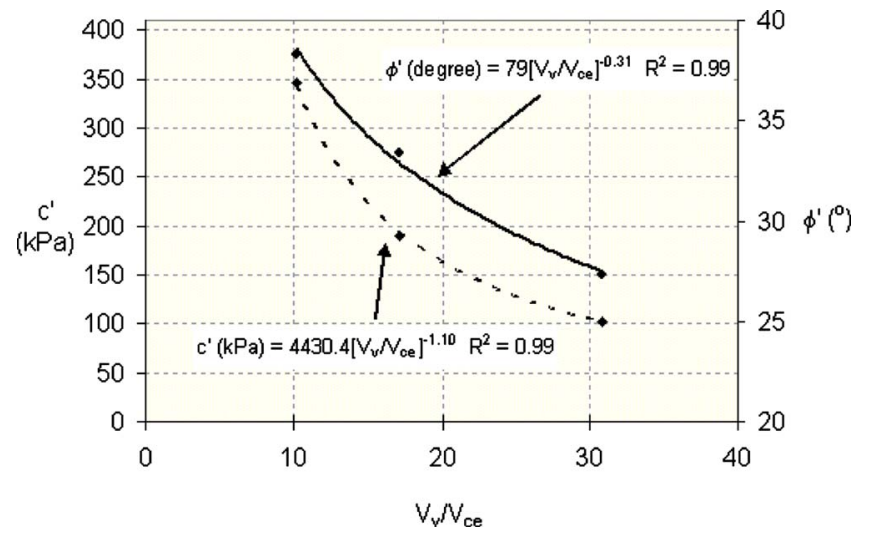

Fig. 4. Peak strength envelopes for $V_{v} / V_{\text {ce }}=10,17$, and 30 considering all triaxial data for each voids/cement ratio, as well as the UCS results

Fig. 5. Relationship of the voids/cement ratio with peak effective strength parameters: cohesion intercept and angle of shearing resistance 


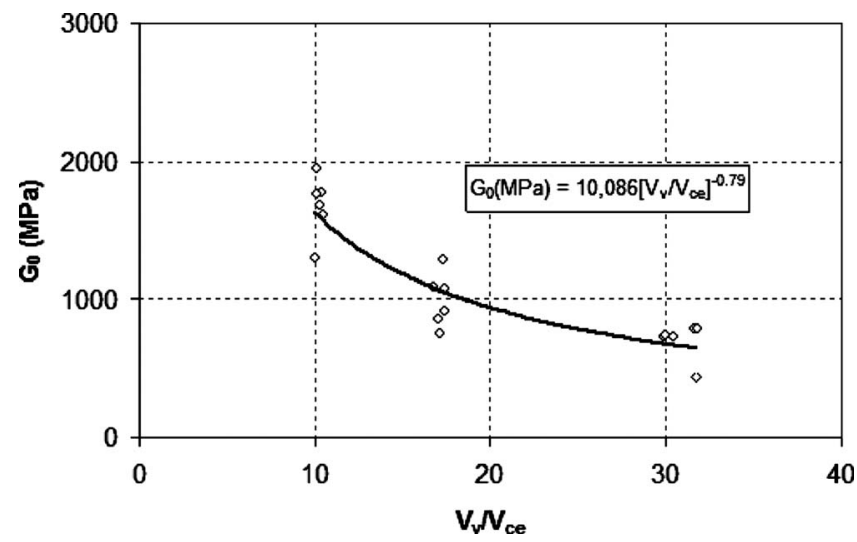

Fig. 6. Relation between $G_{0}$ and $V_{v} / V_{\text {ce }}$ (considering all confining pressures)

$\left(G_{0}\right)$ with voids/cement ratio present similar format and allow establishing a relationship of $G_{0} / q_{u}$ as a function of $V_{v} / V_{\text {ce }}$ [see Eq. (9)]

$$
\frac{G_{0}}{q_{u}} \cong 345\left[\frac{V_{v}}{V_{\mathrm{ce}}}\right]^{0.56}
$$

Finally, the results presented in this paper therefore suggest that using the voids/cement ratio as represented by absolute volume of voids divided by absolute volume of cement $\left(V_{v} / V_{\text {ce }}\right)$, the engineer can choose the amount of cement and the porosity appropriate to provide a mixture that meets the strength and stiffness required by the project at the optimum cost. The voids/cement ratio can also be useful in the field control of soil-cement layers. Once a poor compaction has been identified, it can be readily taken into account in the design, through the $q_{u}, c^{\prime}, \phi^{\prime}, G_{0}$ and even $G_{0} / q_{u}$ versus voids/cement ratio $\left(V_{v} / V_{\text {ce }}\right)$ curves, and adopting corrective measures accordingly such as the reinforcement of the treated layer or the reduction in the load transmitted.

\section{Conclusions}

From the data presented in this paper and bearing in mind the limitations of this study (results are valid for the studied sand and cement), the following conclusions can be drawn:

1. The peak strengths ( $q$ for each effective confining pressure), as well as for the whole deviator stress-axial strainvolumetric strain curve up to peak (for the same $V_{v} / V_{\text {ce }}$ ratio) are about the same, confirming that $V_{v} / V_{\mathrm{ce}}-q_{u}$ correlation holds for specimens under effective confining pressures, and normalization can be extended to the whole deviator stressaxial strain-volumetric strain curve (at least up to peak and consequent opening of a shear band in the specimens).

2. Values of $q_{u}, q$ (consequently $c^{\prime}$ and $\phi^{\prime}$ ), and $G_{0}$ reduce with increasing $V_{v} / V_{\text {ce }}$ values. A relationship $G_{0} / q_{u}$ as a function of $V_{\mathrm{v}} / V_{\text {ce }}$ was established [see Eq. (9)] and is of great practical interest once that it shows that having determined $q_{u}$ and for a given $V_{v} / V_{\text {ce }}, G_{0}$ might be easily instituted. Further research must be carried out to check such relationship for other soils and cementitious materials.

3. The results presented in this paper therefore suggest that using the voids/cement ratio as represented by absolute volume of voids divided by absolute volume of cement $\left(V_{v} / V_{\text {ce }}\right)$, the practitioners may choose the amount of cement and the compaction effort appropriate to provide a mixture that meets the strength and stiffness required by the project at the optimum cost.

\section{Acknowledgments}

The writers express their gratitude to the Brazilian MCT/CNPq (projects Edital Universal 2008, Produtividade em Pesquisa and PNPD), PRODOC/CAPES, and to FCT for their support to the research group.

\section{Notation}

The following symbols are used in this technical note:

$B=$ pore pressure parameter;

$\mathrm{CP}=$ effective confining pressure;

$c^{\prime}=$ effective cohesion intercept;

$D_{50}=$ effective diameter;

$G_{0}=$ initial shear modulus;

$L=$ tip to tip length between the elements;

$q=$ peak deviator stress;

$q_{u}=$ unconfined compression strength;

$R^{2}=$ coefficient of determination;

$t=$ travel time of the shear wave through the sample;

$V_{\text {ce }}=$ volume of cement;

$V_{s}=$ velocity of the shear wave;

$V_{v}=$ volume of voids;

$\gamma_{d}=$ dry density;

$\varepsilon_{a}=$ axial strain;

$\varepsilon_{v}=$ volumetric strain;

$\rho=$ total mass density of the soil;

$\phi^{\prime}=$ effective angle of shearing resistance; and

$\omega=$ moisture content.

\section{References}

ASTM. (1993). "Standard classification of soils for engineering purposes." ASTM D 2487-93, Philadelphia.

Brazilian Standard Association. (1991). "Ordinary portland cement." NBR 5732, Rio de Janeiro, Brazil.

British Standard Methods of Test. (1990). "Soil for civil engineering purposes." BS 1377, London.

Clough, G. W., Sitar, N., Bachus, R. C., and Rad, N. S. (1981). "Cemented sands under static loading." J. Geotech. Engrg. Div., 107(6), 799-817.

Consoli, N. C., Foppa, D., Festugato, L., and Heineck, K. S. (2007). "Key parameters dictating for strength control of artificially cemented soils." J. Geotech. Geoenviron. Eng., 133(2), 197-205.

Consoli, N. C., Lopes, L. S., Jr., Foppa, D., and Heineck, K. S. (2009). "Key parameters dictating strength of lime/cement-treated soils." Proc., Institution of Civil Engineers-Geotechnical Engineering, 162(2), 111-118.

Consoli, N. C., Rotta, G. V., and Prietto, P. D. M. (2006). "Yieldingcompressibility-strength relationship for an artificially cemented soil cured under stress." Geotechnique, 56(1), 69-72.

Consoli, N. C., Vendruscolo, M. A., and Prietto, P. D. M. (2003). "Behavior of plate load tests on soil layers improved with cement and fiber." J. Geotech. Geoenviron. Eng., 129(1), 96-101.

Dalla Rosa, F., Consoli, N. C., and Baudet, B. A. (2008). "An experimental investigation of the behaviour of artificially cemented soil cured under stress." Geotechnique, 58(8), 675-679.

Dyvik, R., and Madshus, C. (1985). "Lab measurements of $G_{\max }$ using 
bender elements." Proc., Advances in the Art of Testing Soils under Cyclic Conditions, ASCE, New York.

Goto, S., Tatsuoka, F., Shibuya, S., Kim, Y. S., and Sato, T. (1991). "A simple gauge for local small strain measurements in the laboratory." Soils Found., 31(1), 169-180.

Horpibulsuk, S., Miura, N., and Nagaraj, T. S. (2003). "Assessment of strength development in cement-admixed high water content clays with Abram's law as a basis." Geotechnique, 53(4), 439-444.

Huang, J. T., and Airey, D. W. (1998). "Properties of an artificially cemented carbonate sand." J. Geotech. Geoenviron. Eng., 124(6), 492499.

Jovicic, V., Coop, M. R., and Simic, M. (1996). "Objective criteria for determining $G_{\max }$ from bender element tests." Geotechnique, 46(2), 357-362.

La Rochelle, P., Leroueil, S., Trak, B., Blais-Leroux, L., and Tavenas, F. (1988). "Observational approach to membrane and area corrections in triaxial tests." Proc., Symp. on Advanced Triaxial Testing of Soil and Rock, ASTM, Philadelphia, 715-731.

Maswoswe, J. J. (1985). "Stress path method for a compacted soil during collapse due to wetting." Ph.D. thesis, Univ. of London, London.
Mitchell, J. K. (1981). "Soil improvement-State-of-the-art report." Proc., 10th Int. Conf. on Soil Mechanics and Foundation Engineering, International Society of Soil Mechanics and Foundation Engineering, Stockholm, 509-565.

Porbaha, A., Shibuya, S., and Kishida, T. (2000). "State of the art in deep mixing technology: Part III-Geomaterial characterization." Ground Improvement, J. ISSMGE, 4(3), 91-110.

Tatsuoka, F., and Shibuya, S. (1992). "Deformation characteristics of soils and rocks from field and laboratory tests." Proc., Keynote Lecture for Session No. 1, 9th Asian Regional Conf. on SMFE, Vol. 2, Balkema, Rotterdam, The Netherlands, 101-170.

Thomé, A., Donato, M., Consoli, N. C., and Graham, J. (2005). "Circular footings on a cemented layer above weak foundation soil." Can. Geotech. J., 42(6), 1569-1584.

Viana da Fonseca, A., Ferreira, C., and Fahey, M. (2009). "A framework interpreting bender element tests, combining time-domain and frequency-domain methods." Geotech. Test. J., 32(2), 91-107.

Viggiani, G., and Atkinson, J. H. (1995). "Stiffness of fine-grained soils at very small strains." Geotechnique, 45(2), 249-265. 